\title{
A comparative study of carbohydrate component of hen and human glycophorins
}

\author{
T. V. Stasyk, H. Krotkiewski', M. D. Lutsik-Kordovsky \\ Division of Regulatory Cell Systems, A. V. Palladin Institute of Biochemistry, National Academy of Sciences of Ukraine \\ 14/16 Drahomanov str., Lviv, 290005, Ukraine \\ 'Depariment of Immunochemistry, Ludwik Hirszfeld Institute of Immunology and Experimental Therapy, Polish Academy of Sciences \\ 53-114 Wroclaw, Poland
}

\begin{abstract}
Sialoglycoproteins (SGPS) from plasma membranes of hen red blood cells were isolated by preparative $S D S-P A G E$ and their carbohydrate composition and some immunochemical properties were investigated and compared with that of human glycophorin A. It was shown, that two principal SGPS with molecular weights of $28 \mathrm{kDa}$ and $55 \mathrm{kDa}$ are monomeric and dimeric forms of the same molecule and are immunochemically closely related. The amount of carbohydrate component consists about $33 \%$ of molecular mass (in human glycophorin $A$ it is $52.3 \%$ ). The analysis of monosaccharide composition of hen SGPs indicates, that they possess $O$-linked and $N$-linked oligocaccharide chains. In comparison with human glycophorin $A$ hen SGPs have a higher amount of $N$-glycosidic chains and lower amount of $O$-glycosidic chains, the last are tentatively of more branched structure.
\end{abstract}

Introduction. Glycophorins are major integral sialoglycoproteins of red blood cell (RBC) membrane, which play an important role in the formation of carbohydrate structure of cell surface. Their characteristic feature is a large carbohydrate moiety, consisting about a half of the molecular mass, which is composed for a number of richly sialilated O-linked oligosaccharide chains. The structures of genes, polypeptide and carbohydrate chains of glycophorins are well studied in man and some other mammals $[1-4]$. Recently we have communicated about the presence and some properties of glycophorin-like molecules in nucleated hen erythrocytes [5]. In present article we report results of the investigation of carbohydrate component of hen glycophorin as well as some immunological study.

Materials and Methods. Fresh blood from white leghorn hens (Gallus domesticus) was obtained on poultry farm during slaughter. $0.1 \mathrm{M}$ sodium oxalate was used, as anticoagulant, in relation 1:10. Blood cells were separated by centrifugation for $10 \mathrm{~min}$ at $1000 \mathrm{~g}$ and buffy coat and supernatant were removed (C) T. V. STASYK, H. KROTKIYWSKI, M. D. LLITSIK-KORDOYSKY, by aspiration. Erythrocytes were washed 3 times with phosphate-buffered saline (PBS) - $0.01 \mathrm{M}$ phosphate buffer, $0.15 \mathrm{M} \mathrm{NaCl}$, pH 7.2 with careful removal of buffy coat at each washing.

Plasma membranes were isolated as we described in $[5]$.

Sialoglycoproteins were obtained from the membranes by extraction with chloroform-isopropanol system according to modified method of Hamagushi [6]. In our modification of the method isopropanol was used instead of methanol and the final proportion of water:alcohol:chloroform was 1:2:4 [7].

Electrophoretically pure glycophorin fractions were obtained from extracted material by preparative electrophoresis in polyacrylamide gel. The procedure of preparative electrophoresis and electroclution of glycoprotein fractions was carried out as described in [8]. Isolated hen glycophorin fractions were used for re-electrophoresis, analysis of carbohydrate composition and immunization of rabbits.

Analytical electrophoresis was carried out in polyacrylamide slab gels in the buffer system of Laemmli $[9]$ with gradient of acrylamide concentration $5-17.3 \%$. Gels were stained consequently by periodic acid - Shiff reagent (PAS) $[10]$ and the- 
reafter with Coomassie Brilliant Blue R-250. In some experiments clectrophoregramms were transferred onto nitrocellulose sheets (Millipore, HA type, $0.45 \mu \mathrm{m}$ ) by electroblotting under conditions described by Towbin et al. [11]. Glycoprotein fractions on blots were detected with HRP-labelled peanut agglutinin (PNA) after desialylation of blots by incubation in $0.05 \mathrm{M}$ sulfuric acid for $50 \mathrm{~min}$ at $80{ }^{\circ} \mathrm{C}$.

For immunoblotting the following buffers were used: PBS with $0.05 \%$ Tween-20, pH 7.4 (PBS-T); and $0.05 \mathrm{M}$ Tris- $\mathrm{HCl}$ buffer, $0.15 \mathrm{M} \mathrm{NaCl}, 0.05 \%$ Tween-20, pH 8.4 (TBS-T). Treatment of nitrocellulose blots with antibodies included the following steps: 1) incubation in PBS-T for $30 \mathrm{~min}$ at room temperature; 2) overnight incubation at $4{ }^{\circ} \mathrm{C}$ in the rabbit anti-hen glycophorin antiserum diluted 1:40 with PBS-T; 3) washing with TBS-T; 4) incubation in hen anti-rabbit IgG antibodies conjugated with HRP in concentration $2 \mu \mathrm{g} / \mathrm{ml}$ in TBS-T; 5 ) washing of the unbound anti-IgG antibodies with TBS-T; 6) detection of peroxidase activity by 4-chloro-1-naphtol reagent, as described in [9].

Anti-rabbit IgG antibodies were obtained by immunization of hens with rabbit IgG, purification of antibodies by affinity chromatography, followed by labelling with HRP according to the method of Nakane et al. [12].

Protein was determined by the method of Lowry et al. [13] or the BCA method [14]. Sialic acid was quantified according to Jourdian [15]. Monosaccharides were determined by gas-liquid chromatography (GLC-MS) as alditol acetates [16], after hydrolysis in $4 \mathrm{M}$ trifluoroacetic acid (TFA) for $4 \mathrm{~h}$ at $100^{\circ} \mathrm{C}$, reduction with sodium borohydride and peracetylation in pyridine/acetic anhydride $1: 1(\mathrm{v} / \mathrm{v})$ at $100{ }^{\circ} \mathrm{C}$ for 35 min. For GLC-MS a Hewlett-Packard 5890 instrument was used, equipped with a mass selective detector 5971A. Separations were performed on a capillary column HP-1 $(0.2 \mathrm{~mm} \times 12 \mathrm{~m})$ with a temperature gradient $150-230^{\circ} \mathrm{C}\left(8^{\circ} \mathrm{C} / \mathrm{min}\right)$.

Results and Discussions. Glycoproteins of hen red blood cells, extracted from isolated plasma membranes with chloroform-isopropanol mixture, resolved in SDS-PAGE into four principal fractions with molecular weights (m. w.) of 28 and $55 \mathrm{kDa}$ as well as 130 and $155 \mathrm{kDa}$ (Figure, a). As we have shown earlier [5], the properties of sialoglycoproteins with $\mathrm{m}$. w. of 28 and $55 \mathrm{kDa}$, including an interaction with lectins, most closely resemble that of human and other mammalian glycophorins.

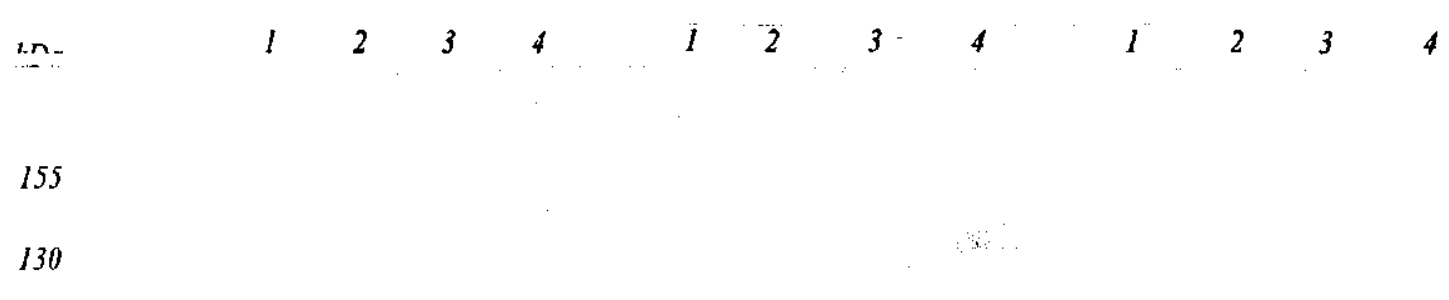

55

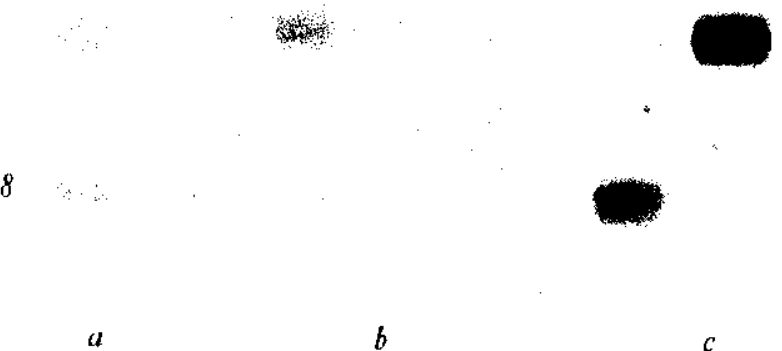

$a$

$d$

\footnotetext{
a - SDS-PAGE of hen red blood cell sialoglycoproteins, $200 \mu \mathrm{g}$ of substance per lane, staining with PAS-reagent; $b$ - sialoglycoprotein fractions obtained by preparative SDS-PAGE, $20 \mu \mathrm{g}$ of protein per lane, staining with PAS-reagent, thereafter with Coomassi Brillsant Blue R-250; $c$ - - lectinoblotting with P'NA-HIRP, monomer $(28 \mathrm{kDa})$ was obtained from dimer $155 \mathrm{kDa})(l)$ and vice versa $(2)$ by repetitive preparative electrophoresis, $5 \mu \mathrm{g}$ of protein per lane; $d$ - immunobiutting with rabbit antiserum to $28 \mathrm{kDa}$ glycoprotein, $3 \mu \mathrm{g}$ of protein per lane. Specimens of glycoproteins with m. w. of $28 \mathrm{kDa}(1), 55 \mathrm{kDa}(2), 130 \mathrm{kDa}$ (3), $155 \mathrm{kDa}$ (4)
} 
The main sialoglycoproteins of hen $\mathrm{RBCs}$ with $\mathrm{m}$. w. 28 and $55 \mathrm{kDa}$ were obtained in pure state by preparative SDS-PAGE. During re-electrophoresis of isolated individual fractions the interconvertion of 28 and $55 \mathrm{kDa}$ bands was observed (Figure, b). In preparation of $28 \mathrm{kDa}$ fraction small amount of 55 $\mathrm{kDa}$ band was always present due to the formation of dimer, as well as in $55 \mathrm{kDa}$ fraction a small band of $28 \mathrm{kDa}$ was formed due to disintegration of dimer. The property of interconvertion was employed for further purification of 28 and $55 \mathrm{kDa}$ glycoproteins by preparative electrophoresis.

Electrophoretically isolated glycoprotein fractions $28 \mathrm{kDa}$ and $55 \mathrm{kDa}$ were submitted to repetitive electrophoresis, during which $28 \mathrm{kDa}$ fractions formed some $55 \mathrm{kDa}$ dimer, while $55 \mathrm{kDa}$ fractions partially decomposed and formed $28 \mathrm{kDa}$ monomeric fractions. Isolated in such way glycoproteins of $28 \mathrm{kDa}$ and $55 \mathrm{kDa}$ were pure enough for analytical investigation (Figure, $c$ ).

The carbohydrate composition of glycoproteins with $\mathrm{m}$. w. 28 and $55 \mathrm{kDa}$ is presented in the Table. The data distinctly indicates that hen SGPs contain both $\mathrm{O}$-type and $\mathrm{N}$-type oligosaccharide chains, the last are much more numerous, as in human glycophorin A. This is evident from the proportion of Man:GalNAc, which is equal 1.7 in avian glycophorin and only 0.2 in human glycophorin A. Additionally, the proportion of GlcNAc:GalNAc is higher in hen SGPs, then in human glycophorin A (1.6 against 0.3, respectively), which also may be caused by a higher number of $\mathrm{N}$-type glycosidic chains. It may be noted also a higher relation of Gal:GalNAc in hen SGPs, as compared to human glycophorin $A$, which may be explained by more branched structure of O-glycosidic chains rich in lactosamine fragments in hen SGPs. The quantification of sialic acid indicates, that the number of O-giycosidic chains in hen SGPs is distinctly lower, then in human glycophorin A. According to analytical data carbohydrate component in hen glycophorin consisted about $33 \%$ of masse of molecule.

Polyclonal antibodies against $28 \mathrm{kDa}$ hen glycophorin bound on immunoblots with monomeric and dimeric fraction of the glycoprotein, to a lesser extent with 130 and $155 \mathrm{kDa}$ SGPs also (Figure, $d$ ). The nature of last SGPs is obscure to us. By relatively high molecular weight they resemble leukosialin, a major SGP of mammalian leukocytes [17]. Nevertheless, binding of these glycoproteins with antibodies against $28 \mathrm{kDa}$ SGP suggests some immunological relations between these glycoproteins. Furthermore, after re-electrophoresis of 130 and $155 \mathrm{kDa}$ glycoproteins weak bands with $\mathrm{m}$. w. 28 and $55 \mathrm{kDa}$ appeared on immunoblots.

The results of investigation of hen $\mathrm{RBC}$ sialoglycoproteins showed that SGPs with $m$. w. of 28 and $55 \mathrm{kDa}$ resembles closely glycophorins of mammals. However, they differ from the last by higher amount of $\mathrm{N}$-glycans and more branched glycosidic chains of O-type.

Acknowledgements. We thank Prof. E. Lisowska and Dr. M. Duk for help and valuable advices in the course of this investigation.

\begin{tabular}{|c|c|c|c|c|c|c|}
\hline \multirow{2}{*}{ Monosaccharide } & \multicolumn{2}{|c|}{ Fraction $28 \mathrm{kDa}$} & \multicolumn{2}{|c|}{ Fraction $55 \mathrm{kDa}$} & \multicolumn{2}{|c|}{ Human glycopherin A } \\
\hline & $\%^{*}$ & mol $\% * *$ & $\%$ & mol $\%$ & $\%$ & mot $\%$ \\
\hline Fucose & 1.3 & 5.8 & 1.6 & 6.4 & 0.5 & 1,4 \\
\hline Mannose & 4.6 & 18.4 & 3.9 & 14.1 & 1.6 & 4.3 \\
\hline Galactose & 6.0 & 23.8 & 7.2 & 26.1 & 9.3 & 24.7 \\
\hline GICNAC & 5.7 & 18.4 & 5.9 & 17.5 & 3.4 & 7.2 \\
\hline GalNAC & 3.3 & 10.7 & 3.9 & 11.5 & 10.3 & 21.9 \\
\hline Sialic acid & 10.0 & 22.8 & 11.6 & 24.4 & 27.2 & 40.4 \\
\hline Protein & 68.8 & - & 65.7 & - & 47.7 & - \\
\hline
\end{tabular}

*Sum of carbohydrates and protein estimated by $\mathrm{BCA}$ method was taken as $100 \%$; ** number of moles of each carbohydrate per 100 moles of all carbohydrates. 


\section{Т. в. Стасик, Г. Кроткевський, М. Д. Луцик-Кордовський}

Порівняльне дослідження вуглеводного компонента глікофоринів курей і людини

Резюме

Одержано сіалоглікопротеїни (СГЛ) плазматичяих мембран еритроцитів курей за допомогою препаративного електрофорезу в поліакриламідному гелі в присутності $\mathrm{DS}-\mathrm{Na}$. Досліджено іх вуглеводнии склад у порівнянні з глікофорином $A$ людини, а також деякі імунологічні властивості. Показано, що соловні СГП з молекулярнюю масою 28 i 55 кДа 6 мономерною і димерною формами однієї молекули, які імунологічно близькоспоріднені. Вуглеводний компонент складає біля $33 \%$ молекулярної маси цього глікопротеїну (у глікофорині А людини-52,3 \%). Аналіз моносахаридиого складу СГЛ курей свідиить, шо вони містять як O-, так $i \mathrm{~N}$-зв'язані олігосахаридні ланцюги у порівнянні з глікофорином А людини СГП курей вміщують більиу кількість $N$-глікозидних $і$ мениу кількість О-глікозидних панцюгів, при цьому останні є більи розгалуженої будови.

\section{Т. В. Стасык, Х. Кроткевский, М. Д. Луцик-Кордовский}

Сравнительное исследование углеводного компонента гликофоринов кур и человека

\section{Резюме}

Получень сиалохликопротеины (СГI) плазматических мембран эритроцитов кур с помоцью препаративного электрофореза в полиакриламидном геле в присутствии $D S-\mathrm{Na}$. Исследован их углеводный состав в сравнении с гликофорином $A$ иеловека, а также некоторые иммунолосические сөойства. Ноказано, что главные СГП с молекулярной массой 28 и 55 кДа являются мономерной и димерной формами одной и той же молекулы и иммунологически близкородственны. Углеводный компонент составлиет около 33 \% молекулярной массы этосо сликопротеина (з гликофорине $A$ человека $-52,3 \%$ ). Анализ моносахаридного состава СГЛ куриць сяидетельствуem о том, 'ето они содержат как $O$-, так и $N$-связанные олигосахаридные цепи. ПІо сравнению с гликофорином А человека СГП кур содержат больиее количество $N$-гликозидных и меньиее количество $O$-гликозидных цепей, при этом последние имеют более разветвленную структуру.

\section{REFERENCES}

1. lisowska $E$. Antigenic properties of human erythrocyte glycophorins // Molecular imınunology of compiex carbohydrates / Ed. A. M. Wu.-New York and London: Plenum press, 1988. - P. $265-315$.

2. Cartron J.-P., Rahuel C. Human erythrocyte glycophorins: protein and gene structure analysis // Trans. Med. Rev.1992.-6, № 2.-P. 63-92.
3. Krotkiewski $H$. The structure of glycophorins of animal erythrocytes // Glycoconjugate J. $-1988 .-5 .-P .35-48$.

4. Huang C. H., Xie S. S., Socha W., Blumenfeld $O$. $O$. Sequence diversification and exon inactivation in the glycophorin A gene family from chimpanzee to human $/ / \mathrm{J}$. Mol. Evol.-1995.-41.-P. $478-487$.

5. Стасик T. В., Луцик-Кордовський М. Д. Одержання і властивості глікофорину плазматичної мембрани еритроцитів курей // Біополімери і клітина,-1996.-12, № 4.-C. 94-99.

6. Hamaguchi $H$. Cleve $H$. Solubilization and comparative analysis of mammalian erythrocyte membrane glycoproteins // Biochem. and Biophys. Res. Communs. $-1972 .-47$, № 2.P. 459-464.

7. Луцик М. Д., Олешко П. С., Цегельский А. А. Получение н частичная характеристика волорастворимых мембранных гликоиротеинов - рецепторов лектинов // Биол. мембраны. - 1992. -9, № 10-11.-C. 1025-1027.

8. Луцик М. А., Олеико П. С., Вовканич А. С. Електроелюювання білкових фрахцій з поліакриламідного гелю // Укр. біохім. жури.-1990.-62, № 1.-C. $112-115$.

9. Laemmli $U . K$ Cleavage of structural proteins during the assembly of the head of bacteriophage T4// Nature. -1970 .277, № 5259.-P. 680--685.

10. Луцик М. Д., Кусень С. Й. Исследование мембранных гликонротеинов эритроцитов чсловека с применением лектинов // Укр. биохим. журн. -1987.-59, № 6.-С. 3-9.

11. Towbin $M$., Stehelin T., Gordon $J$. Electrophoretic transfer of protein from polyacrylamide gels to nitrocellulose sheets: procedure and some applications // Proc. Nat. Acad. Sci. USA.-1979.-76, № 9.-P. 4350-4354.

12. Nakane $P$., Kawaoi $A$. Peroxidase-labelled antibody. A new method of conjugation // J. Histochem. and Cytochem.1974.-22, № 12.-P. 1084-1091.

13. Lowry O. H., Rosenbrough N. J., Farr A. L., Randall R. J. Protein measurement with the Folin phenol reagent // J. Biol. Chem. -1951.-193.-P. 265-275.

14. Smith P. K., Krohn R. I., IIermanson G. T. et al. Measurement of protein using bicinchoninic acid // Anal. Biochem.1985.-150.-P. $76-85$.

15. Jourdian G., Dean $L .$, Roseman $S$. The sialic acid. A periodate-resorcinol method for the quantitative estimate of sialic acid and their glycosides // J. Biol. Chem.-1976.--246, № 2.-P. $430-435$.

16. Sawardeker J. S,, Sloneker J. H., Jeanes A. Quantitative determination of monosaccharides as their alditol acetates by gas liquid chromatography // Anal. Chem.-1965.-37.P. $1602-1604$.

17. Fukuda $M$. Leukosialiu, a major O-glycan-containing sialoglycoprotein defining leukocyte differentiaton and malignancy // Glycobiology, -1991.-1, N 4,-P. 347-356.

Received 21.08.97 